\title{
PELAKSANAAN KEBIJAKAN PIMPINANTERHADAP MODEL KOMPETENSI DOSEN AKADEMI KEPERAWATAN YPDR JAKARTA
}

\author{
Erialdy ${ }^{1}$, Sugeng Lubar Prastowo ${ }^{2}$, Ade Indra Permana ${ }^{3}$ \\ ${ }^{123}$ Universitas Islam Syekh-Yusuf \\ erialdy@unis.ac.id ${ }^{1}$, slubar@unis.ac.id ${ }^{2}$, aipermana@unis.ac.id ${ }^{3}$
}

\begin{abstract}
Abstrak
Dosen dalam proses pembelajaran mempunyai tanggung jawab akan keberhasilan peserta didik. Keberhasilan kompetensi lulusan sangat tergantung dari kualitas Dosen dalam penyampaian mata ajaran kepada peserta didik. Semakin baik kompetensi dosen maka semakin baik mutu lulusan. Penelitian ini menggunakan metode kualitatif deskriptif, Teknik pengumpulan data menggunakan wawancara mendalam, studi dokumentasi. Wawancara dilakukan dengan: (1) Direktur Akademi Keperawatan YPDR Jakarta, (2) Pembantu Direktur Bidang Administrasi dan Kepegawaian, Untuk studi dokumentasi, data dikumpulkan dari file dan dokumentasi yang dimiliki oleh Akademi Keperawatan YPDR Jakarta. Analisis data menggunakan empat tahap yaitu pengumpulan data, reduksi data, penyajian data dan penarikan kesimpulan atau verifikasi. Pengujian keabsahan data menggunakan teknik triangulasi sumber. Hasil penelitian pelaksanaan model kompetensi Dosen yang dikembangkan oleh Direktur Akademi Keperawatan YPDR Jakarta merupakan deskripsi tertulis tentang kompetensi yang dibutuhkan untuk mencapai kinerja tinggi atau teladan dalam kategori pekerjaan, kerja tim dalam institusi untuk menjawab tantangan internal institusi dan mempertahankan keunggulan kompetitif serta meningkatkan kinerja institusi dengan berlandaskan pada kompetensi-kompetensi sumber daya manusia.
\end{abstract}

Kata Kunci: Pelaksanaan, Kebijakan, Kompetensi

\section{A. Pendahuluan}

Pendidikan pada hakikatnya memberikan kontribusi terhadap pembangunan bangsa yang secara sinergis membangun sumber daya manusia dari tidak tahu menjadi tahu, dari tahu menjadi terampil dan dari terampil menjadi ahli. Pendidikan diploma tiga (D3) Keperawatan sebagai bagian dari sistem jenjang pendidikan tinggi nasional bertujuan menghasilkan tenaga keperawatan yang kompeten untuk memberikan layanan kepada masyarakat berdasarkan kaidah profesi dan harapan masyarakat di berbagai tatanan layanan kesehatan (Komarudin, 2018).

Direktur atau ketua program studi merupakan orang yang paling berperan dalam menentukan arah pendidikan (Nurlia, U. et al. 2018). Selaku pemimpin di institusi pendidikan Keperawatan Direktur atau Ketua Program studi

$$
\text { merupakan tokoh sentral }
$$

pendidikan. Henry Mintzberg dalam
Wahjosumidjo (2010) menyatakan ada tiga macam peran pemimpin dilihat dari otoritas dan status formalnya. Peran tersebut meliputi interpersonal, informational dan decision roles. (House et al. dalam GaryYukl. 2010) mengatakan kepemimpinan adalah kemampuan individu untuk mempengaruhi, memotivasi, dan membuat orang lain mampu memberikan kontribusinya demi efektifitas dan keberhasilan organisasi.

Pimpinan merupakan penentu kebijakan dari kegiatan yang akan dilaksanakan di institusinya. Kebijakan pimpinan dalam pengelolaan institusi pendidikan berpengaruh terhadap keberhasilan peserta didik. Seorang pemimpin sesuai dengan peran dan fungsinya mempunyai kewenangan dalam mempersiapkan kegiatan pembelajaran yang bermutu, sehingga dapat tercapai lulusan yang diharapkan oleh masyarakat.

$$
\text { Selaku tenaga pendidik }
$$

profesional, Dosen harus memiliki 
kompetensi, tidak hanya sebagai proses transfer pengetahuan, namun Dosen juga dapat menjadi teladan dan model dalam pembentukan kepribadian dan sikap mahasiswa (Nurlia, et al. 2018). Dosen dalam proses pembelajaran mempunyai tanggung jawab akan keberhasilan peserta didik. Keberhasilan kompetensi lulusan sangat tergantung dari kualitas dosen dalam penyampaian mata ajaran kepada peserta didik. Semakin baik kompetensi dosen maka semakin baik mutu lulusan.

Undang-Undang Republik

Indonesia Nomor 14 Tahun 2005 tentang Guru dan Dosen mengemukakan bahwa kompetensi adalah seperangkat pengetahuan, keterampilan, dan perilaku yang harus dimiliki, dihayati, dan dikuasai oleh Guru atau Dosen dalam melaksanakan tugas keprofesionalan. Kompetensi Dosen sebagai pemangku utama dalam proses pembelajaran mempunyai peran yang sangat penting terhadap keberhasilan peserta didik.

Lucia dan Lepsinger, (1999)

seperti yang dikutip Dubois, (2004) bahwa model kompetensi menggambarkan kombinasi pengetahuan, keterampilan, dan karakteristik tertentu yang diperlukan untuk secara efektif melakukan peran dalam sebuah organisasi dan digunakan sebagai alat untuk seleksi, pelatihan dan pengembangan, penilaian, dan perencanaan suksesi sumber daya manusia.

Model kompetensi diperlukan dalam rangka mendukung pelaksanaan manajemen sumber daya manusia yang bertujuan untuk meningkatkan kinerja organisasi, mengidentifikasi kompetensi yang dibutuhkan untuk berkinerja tinggi, mengupayakan untuk menghilangkan kesenjangan kompetensi yang ada, dan mengurangi kesenjangan kompetensi serta memastikan bahwa Dosen yang kompeten secara aktif berpartisipasi dalam manajemen kinerja. Model kompetensi merupakan deskripsi tertulis tentang kompetensi yang dibutuhkan untuk sepenuhnya mencapai kinerja tinggi atau teladan dalam kategori pekerjaan, kerja tim, departemen, divisi atau organisasi.

Menurunnya kinerja organisasi, paradigma sumber daya manusia yang tidak kondusif, budaya organisasi yang tidak favorabel, dan kurangnya sumber daya menjadi tantangan internal bagi institusi, begitu juga datangnya revolusi informasi yang menjelma menjadi globalisasi informasi, yang kemudian mendorong munculnya masyarakat berbasis pengetahuan (knowledge-based society), ekonomi berbasis pengetahuan (knowledge-based economy) dan tenaga kerja berbasis pengetahuan (knowledgebased worker) merupakan tantang eksternal yang harus dihadapi oleh Pimpinan Akademi Keperawatan YPDR Jakarta.

Perubahan-perubahan yang terjadi di lingkungan internal dan eksternal tersebut menjadi tidak hanya penting tetapi pada saat yang sama merupakan tantangan-tantangan strategik yang mendesak bagi Akademi Keperawatan YPDR untuk secepatnya dapat diatasi, dan menjadi alasan yang kuat untuk dilakukannya penelitian tentang Pelaksanaan Kebijakan Pimpinan Terhadap Model Kompetensi Dosen Akademi Keperawatan YPDR Jakarta.

\section{B. Metode}

Penelitian ini menggunakan metode kualitatif deskriftif, yang bertujuan untuk mendeskripsikan pelaksanaan kebijakan Direktur Akademi Keperawatan Jakarta tentang model kompetensi Dosen. Pengumpulan data menggunakan teknik wawancara mendalam, studi dokumentasi. Data primer dilakukan wawancara dengan: (1) Direktur Akademi Keperawatan YPDR Jakarta, orang yang bertanggung jawab untuk pelaksanaan kebijakan Manajemen sumber daya manusia berbasis kompetensi; (2) Pembantu Direktur 
Bidang Administrasi dan Kepegawaian, orang kedua yang bertanggung jawab dalam pelaksanaan manajemen sumber daya manusia berbasis kompetensi. Untuk studi dokumentasi, data dikumpulkan dari file dan dokumentasi y ang dimiliki Akademi Keperawatan YPDR Jakarta.

Analisis data dilakukan dengan menganalisis model kompetensi Dosen yang dikembangkan oleh Direktur Akademi Keperawatan YPDR Jakarta, menggunakan empat tahap yaitu pengumpulan data, reduksi data, penyajian data dan penarikan kesimpulan atau verifikasi. Pengujian keabsahan data menggunakan teknik triangulasi sumber. Penelitian dilakukan tahun 2018.

Akademi Keperawatan YPDR Jakarta adalah institusi yang menyelenggarakan pendidikan vokasional program studi diploma tiga (D3) Keperawatan, dengan izin penyelenggaraan pendidikan dari Kementrian Pendidikan Nasional nomor 221/E/O/2011, berkedudukan di Jakarta Selatan. Visi Akademi Keperawatan YPDR adalah "Pada Tahun 2025 menjadi Akademi Keperawatan YPDR yang unggul di bidang Keperawatan Gawat Darurat dalam mengembangkan tenaga vokasional keperawatan yang berakhlaq mulia dan mampu bersaing secara global", misinya yaitu (1) Mengembangkan pendidikan keperawatan dengan keunggulan teknologi keperawatan komunitas; (2) Membangun budaya riset guna memecahkan masalah kesehatan khususnya di bidang keperawatan; (3) Meningkatkan pengabdian masyarakat sebagai pengamalan ilmu melalui pelayanan keperawatan/kesehatan secara terintegrasi; (4) Mengembangkan kemitraan dengan Lembaga Pendidikan swasta dan pemerintah baik secara Nasional maupun Asia.

Untuk dapat mengatasi tantangan internal yang sesuai (appropriate), sebagai respon terhadap tantangan- tantangan dari lingkungan yang sedang berubah dengan cepat, Akademi Keperawatan YPDR Jakarta melaksanakan dua kebijakan institusi: (1) Melaksanakan menajemen strategik (strategic management) dalam mereformulasi visi, misi dan nilai-nilai organisasi; dan (2). Melaksanakan manajemen sumber daya manusia berbasis Kompetensi (Competency-Based HRM), secara keseluruhan kedua kebijakan ini diyakini sebagai kebijakan yang komprehensif, integratif, dan berpengaruh kuat (leveraging) untuk mengatasi tantangan-tantangan organisasi yang sedang dihadapi.

Langkah-langkah spesifik dan lebih operasional untuk pengembangan kompetensi kompetensi inti dimulai dengan visi, misi dan nilai-nilai organisasi sebagai dasar untuk mengidentifikasi tantangan yang dihadapi, perilaku sumber daya manusia diidentifikasi, dan menetapkan kompetensi sumber daya manusia yang diperlukan. Kompetensi yang dilaksanakan mencakup spektrum kompetensi organisasi seperti berpikir sistem, memimpin dan mengelola, bejejaring dan belajar secara sistemik.

Akademi Keperawatan YPDR Jakarta telah mengembangkan model kompetensi Dosen sejak tahun 2011 dan memperbaruinya setiap tahun dalam menanggapi perubahan yang cepat dari tantangan strategik lingkungan. Model kompetensi Dosen yang dikembangkan oleh Akademi Keperawatan YPDR Jakarta sejak 2018

Model kompetensi Dosen terdiri dari 19 kompetensi, masing-masing memiliki empat tingkat indidikator perilaku yang berbeda. Keempat tingkatan yang berbeda tersebut, rangkingnya dari nilai 1 (kurang), 2 (cukup), 3 (baik) sampai 4 (sangat baik). Jika Dosen mampu menunjukkan kompetensi perilaku sampai dengan indikator perilaku tingkat 4 , maka ini 
menunjukkan bahwa Dosen digolongkan sebagai sangat kompeten.

Secara teknis, unit organisasi yang bertanggung jawab untuk pengembangan model kompetensi Dosen adalah Pembantu Direktur bidang Administrasi dan Kepegawaian, di sisi lain, ketika mengembangkan model kompetensi, semua bagian institusi diundang untuk berpartisipasi dalam proses pengembangan kompetensi Dosen. Dari segi isi, jumlah kompetensi Dosen yang dikembangkan tersebut dapat dikelompokkan menjadi kompetensi yang berkaitan dengan: (1) Berpikir, (2) Belajar, (3) Menjadi profesional dan (4) Memimpin dan mengelola. Pengelompokan kompetensi ini secara rinci diuraikan dalam tabel 2 , di bawah ini :

Untuk tujuan pembelajaran, yang merupakan kebutuhan dasar bagi Dosen adalah dengan merubah pola pergaulan dan komunikasi antar Dosen dalam kehidupan institusi sehari-hari, dari pola komunikasi hirarhi (hierarchy of communication) menjadi pola komunikasi kemitraan dalam jaringan (network of communication), dengan jaringan komunikasi kemitraan pembelajaran akan tumbuh dan berkembang.

\section{Pembahasan}

Kecakapan Direktur Akademi Keperawatan YPDR Jakarta dalam menjabarkan visi, misi dan strategi pendidikan sangat mempengaruhi dalam kemampuannya menjalankan roda institusi, dan salah satu kemampuan itu adalah memotivasi staf dalam menjalankan kegiatan sesuai tujuan institusi. Peran Direktur jadi motor penggerak dalam melaksanakan kebijakan, ditambah dukungan dari segenap civitas akademika termasuk yayasan.

Perubahan-perubahan yang terjadi di lingkungan internal dan eksternal institusi Akademi Keperawatan YPDR Jakarta menjadi tidak hanya penting tetapi pada saat yang sama merupakan tantangan-tantangan strategik yang mendesak bagi institusi untuk secepatnya dapat diatasi, apabila organisasi ini ingin mempertahankan keberhasilannya.

Model kompetensi Dosen yang dikembangkan oleh Akademi Keperawatan YPDR Jakarta sejalan dengan teori model kompetensi yang dijelaskan oleh Lucia dan Lepsinger (1999) dikutip Dubois (2004) bahwa model kompetensi menggambarkan kombinasi pengetahuan, keterampilan, dan karakteristik tertentu yang diperlukan untuk secara efektif melakukan peran dalam sebuah organisasi dan digunakan sebagai alat untuk seleksi, pelatihan dan pengembangan, penilaian, dan perencanaan suksesi sumber daya manusia. Selanjutnya menyatakan bahwa: Model kompetensi menggambarkan kombinasi tertentu dari pengetahuan, keterampilan, dan karakteristik yang diperlukan untuk secara efektif melakukan peran dalam organisasi dan digunakan sebagai alat untuk seleksi, pelatihan dan pengembangan, penilaian, dan perencanaan suksesi sumber daya manusia

Dubois, (et.al, 2004) menjelaskan bahwa model kompetensi biasanya meliputi daftar kompetensi dan indikator perilaku yang membuat kompetensi menjadi hidup dan menarik dalam konteks organisasi. Model kompetensi adalah sekelompok 7 sampai 9 kompetensi yang biasanya diperlukan oleh suatu pekerjaan tertentu dan digambarkan dalam model kompetensi (Ennis, 2008). Model Kompetensi digunakan untuk menyelaraskan kemampuan individual dan fungsi-fungsi sumber daya manusia dengan strategi organisasi.

Terkait dengan kesesuaian dari model kompetensi yang dikembangkan oleh Akademi Keperawatan YPDR Jakarta, sebagai konsep dasar 
pelaksanaan manajemen sumber daya manusia berbasis kompetensi (Graham, 2009) adalah untuk mempertahankan keunggulan kompetitif institusi dengan berlandaskan pada kompetensikompetensi sumber daya manusia. Bagi Akademi Keperawatan YPDR Jakarta untuk meningkat dari kualitas institusi yang baik menjadi terbaik, menggunakan sumber daya manusia yang tepat, yaitu yang kompeten yang bisa menjadi aset organisasi yang benar-benar penting.

$$
\text { Model kompetensi Dosen }
$$

diperlukan dalam rangka mendukung pelaksanaan Manajemen sumber daya manusia berbasis kompetensi yang bertujuan untuk meningkatkan kinerja organisasi melalui: (1) Mengidentifikasi kompetensi yang dibutuhkan untuk berkinerja tinggi; (2) Mengupayakan untuk menghilangkan kesenjangan kompetensi yang ada melalui seleksi dan asesmen yang efektif; (3) Mengurangi kesenjangan kompetensi Dosen melalui pelatihan, pengembangan dan pembelajaran, dan (4) Memastikan bahwa Dosen yang kompeten secara aktif berpartisipasi dalam manajemen kinerja.

Manajemen sumber daya manusia berbasis kompetensi memindahkan fokus perhatian pada individu-individu Dosen serta kompetensi-kompetensi yang dimilikinya dengan mengaitkannya dengan hasil yang ingin dicapai.

\section{Kesimpulan}

Pendidikan diploma tiga (D3) Keperawatan sebagai bagian dari sistem jenjang pendidikan tinggi nasional bertujuan menghasilkan tenaga keperawatan yang kompeten untuk memberikan layanan kepada masyarakat berdasarkan kaidah profesi dan harapan masyarakat di berbagai tatanan layanan kesehatan. Untuk dapat mengatasi tantangan dari lingkungan yang sedang berubah dengan cepat, Pimpinan Akademi Keperawatan YPDR Jakarta melaksanakan dua kebijakan institusi, diantaranya melaksanakan manajemen sumber daya manusia berbasis Kompetensi (Competency-Based HRM), Langkah-langkah spesifik dan lebih operasional dimulai dengan mengidentifikasi perilaku Dosen dan menetapkan kompetensi sumber daya manusia yang diperlukan dengan mengembangkan model kompetensi Dosen Pelaksanaan model kompetensi Dosen yang dikembangkan oleh Direktur Akademi Keperawatan YPDR Jakarta merupakan deskripsi tertulis tentang kompetensi yang dibutuhkan untuk mencapai kinerja tinggi atau teladan dalam kategori pekerjaan, kerja tim dalam institusi sudah sesuai (appropriate) untuk menjawab tantangan internal institusi dan mempertahankan keunggulan kompetitif serta meningkatkan kinerja institusi dengan berlandaskan pada kompetensikompetensi sumber daya manusia. Model kompetensi Dosen yang dikembangkan oleh Akademi Keperawatan YPDR Jakarta, menggambarkan kombinasi pengetahuan, keterampilan, dan karakteristik tertentu yang diperlukan untuk secara efektif digunakan sebagai alat untuk seleksi, pelatihan dan pengembangan, penilaian, dan perencanaan suksesi sumber daya manusia. Pelaksanaan model kompetensi Dosen, metode dan pendekatan yang digunakan berkisar dari yang sederhana sampai yang relatif rumit. Model kompetensi Dosen Akademi Keperawatan YPDR Jakarta yang digunakan, dihasilkan dari proses pengembangan bercirikan perilaku, kausal terhadap kinerja tinggi dan praktis untuk diterapkan. 


\section{E. Referensi}

Akademi Keperawatan YPDR Jakarta (2018), Statuta Akademi Keperawatan YPDR Jakarta.

Cochran, Ralph, Graham. (2009) Ohio State University Extension Competency Study: Developing a Competency Model for a 21st Century Extension Organization, Dissertation.

Dubois, D.David et al. (2004). Competency-Based-Human

Resource Management, DaviesBlack Publishing, 3803 East Bayshore Road, Palo Alto, CA 94303. 2004.

Gary Yukl.(2010). Kepemimpinan Dalam Organisasi, alih bahasa Budi Supriyanto. PT.Indeks. Jakarta

Kementrian Hukum Dan Hak Asasi Manusia Republik Indonesia .(2005). Undang-Undang Republik Indonesia Nomor 14 Tahun Tentang Guru Dan Dosen.

Komarudin. (2018). Pendidikan Keperawatan Berkelanjutan Dalam Pencapaian Sustainability Profesionalisme Keperawatan. Jurnal Penelitian Ipteks Vol. 3 No. 2 Juli 2018 p-ISSN:2459-9921 EISSN:2528-0570 HAL: 139-151

Lisa Dwi Astuti. (2015). Hubungan Kurikulum Program Studi D III
Kebidanan, Kompetensi Dosen, Dan Sarana Prasarana Pendidikan Dengan Mutu Lulusan. Jurnal Kebidanan Pantiwilasa. ejurnal.akbidpantiwilasa.ac.id

Michelle Ennis, Competency (2008). Model: A Review of the Literature and the Role of the Employment and Training Administration (USA: Office of Policy Development and Training Administration U.S. Department of Labor)

Nana Syaodih.S. \& Erliana Syaodih. (2012). Kurikulum \& Pembelajaran Kompetensi. Refika Aditama. Bandung.

Nurlia, U. Husna Asmara, Aswandi. (2018). Peran Ketua Prodi Dalam Pengembangan Kurikulum Berbasis Kompetensi D III Keperawatan. Stikes Yarsi Pontianak. Jurnal Pendidikan dan Pembelajaran Khatulistiwa

Tri Arini, Tenang Aristina, Nunung Rachmawati. (2016). Persepsi Alumni Tentang Pelaksanaan Uji Kompetensi Semester Di Akademi Keperawatan YKY Yogyakarta. Jurnal Keperawatan AKPER YKY, 4 (1). pp. 22-26. ISSN 2356-265X

Wahjosumidjo.(2010). Kepemimpinan Kepala Sekolah: Tinjauan Teoritik dan Permasalahannya. PT. Raja grafindo Persada. Jakarta. 


\section{LAMPIRAN:}

Tabel 1

Model Kompetensi Dosen

\begin{tabular}{|c|l|}
\hline No & \multicolumn{1}{|c|}{ Kompetensi } \\
\hline 1 & Berfikir Inovatif \\
\hline 2 & Berfikir Konseptual \\
\hline 3 & Berfikir Analisis \\
\hline 4 & Berfikir Sintesis \\
\hline 5 & Berfikir Strategis \\
\hline 6 & Perbaikan Berkelanjutan \\
\hline 7 & Pembelajaran Berkelanjutan \\
\hline 8 & Integritas \\
\hline 9 & Kepercayaan \\
\hline 10 & Orientasi Pelayanan \\
\hline 11 & Orientasi Pemangku Kepentingan \\
\hline 12 & Orientasi Prestasi \\
\hline 13 & Perencanaan dan Pengorganisasian \\
\hline 14 & Komunikasi \\
\hline 15 & Persuasi \\
\hline 16 & Advokasi \\
\hline 17 & Kemitraan \\
\hline 18 & Pengambilan Keputusan \\
\hline 19 & Mengembangkan orang lain \\
\hline
\end{tabular}

Sumber: Pengolahan Data

Tabel 2

Kelompok Kompetensi

\begin{tabular}{|c|c|}
\hline Kelompok & Kompetensi \\
\hline \multirow{5}{*}{ Berpikir } & 1. Berfikir Inovatif \\
\hline & 2. Berfikir Konseptual \\
\hline & 3. Berfikir Analisis \\
\hline & 4. Berfikir Sintesis \\
\hline & 5. Berfikir Strategis \\
\hline \multirow{2}{*}{ Belajar } & 6. Perbaikan Berkelanjutan \\
\hline & 7. Pembelajaran Berkelanjutan \\
\hline \multirow{5}{*}{ Menjadi profesional } & 8. Integritas \\
\hline & 9. Kepercayaan \\
\hline & 10. Orientasi Pelayanan \\
\hline & 11. Orientasi Pemangku Kepentingan \\
\hline & 12. Orientasi Prestasi \\
\hline \multirow{7}{*}{$\begin{array}{l}\text { Memimpin dan } \\
\text { mengelola }\end{array}$} & 13. Perencanaan dan Pengorganisasian \\
\hline & 14. Komunikasi \\
\hline & 15. Persuasi \\
\hline & 16. Advokasi \\
\hline & 17. Kemitraan \\
\hline & 18. Pengambilan Keputusan \\
\hline & 19. Mengembangkan orang lain \\
\hline
\end{tabular}

Sumber: Pengolahan Data 